ESJ Humanities

\title{
Evaluating the German Position Towards Asylum Seekers During the 2015 European Refugee Crisis
}

\author{
Muhammad Ahsan Jamal \\ Shanghai Jiaotong University, China \\ Yue Xie \\ Soochow University, China
}

$\underline{\text { Doi:10.19044/esj.2021.v17n28p18 }}$

Submitted: 12 May 2021

Accepted: 16 August 2021

Published: 31 August 2021
Copyright 2021 Author(s)

Under Creative Commons BY-NC-ND

4.0 OPEN ACCESS

Cite As:

Jamal M. A. \& Xie Y. (2021). Evaluating the German Position Towards Asylum Seekers During the 2015 European Refugee Crisis. European Scientific Journal, ESJ, 17 (28), 18.

https://doi.org/10.19044/esj.2021.v17n28p18

\begin{abstract}
The refugee crisis that emerged in 2015 was considered to be one of the worst political and humanitarian disasters and the huge influx of immigrants that arrived in Europe caused collective concerns among the receiving countries. The general attitude towards immigrants in Germany has been positive for years but the Syrian crisis prompted the German policies to become more lenient towards the refugees. Therefore, this paper analyzes Germany's policy shift towards refugees after 2015 and examines the reasons behind the positive stance towards immigrants from the existing literature. The paper discusses the role of different factors ranging from economic, foreign policy considerations, ideological concerns to humanitarian values. In addition, this paper highlights the gaps in the literature and proposes directions for future research to comprehend German policies on immigrants. The research concludes with the findings that humanitarian values and past experiences have played a crucial role in shaping Germany's refugee policy during the European refugee crisis.
\end{abstract}

Keywords: Germany, Immigration Policy, Refugees, Refugee Crisis, Integration 


\section{Introduction}

As conflict and oppression engulfed the Middle East and North African region, millions of people were forced to flee their homes and seek refuge in Europe and elsewhere. The year 2015 witnessed one of the worst humanitarian crises, as the United Nations Refugee Agency report revealed that worldwide displacement was recorded at the highest level than any other time. During the height of the refugee crisis, the number of forcibly displaced people reached 59.5 million in 2015 (UNHCR, 2015), while the number of refugees in Europe was estimated to be around 6.7 million by the end of the year.

Initially, the crisis in Syria, Iraq, Afghanistan, and North Africa led the local population to leave their homes and take refuge in neighboring countries. Although Syria, Iraq, and Afghanistan's neighbors Turkey, Pakistan, and Lebanon accounted for the highest number of refugees during 2015 that is 2.9 million, 1.4 million, and 1 million respectively (UNHCR, 2016). However, the internal policies, mismanagement and social disorder led many immigrants to move to Europe. Consequently, the media coverage on refugees termed the crisis as a "European refugee crisis", while international NGOs continued to point out that Western countries are not supporting a fair share of displaced people.

The refugee crisis posed an unprecedented challenge to the European nations and forced the governments to revise their immigration policies. The European Union (EU) witnessed the largest flow of asylum seekers and started to set up refugee camps all over Europe. Despite the collective concerns of other European states, Germany opened its border to refugees and became the most welcoming nation towards the refugees. Therefore, it is worth examining the reasons behind Germany's positive attitude toward refugees during the 2015 crisis and German political leaders' decision to allow asylum seekers to seek refuge in the country.

The main focus of this paper will be to analyze the rationale behind Germany's policy to allow immigrants from a theoretical perspective. The paper studies literature and examines the reasons ranging from economic incentives, foreign policy considerations, historical experiences, humanitarian concerns as well as respective roles of these factors in shaping Germany's policies towards refugees. In addition, this article also highlights the gaps in literature and points out the factors that directly influenced Germany's immigration policy and decision-making during the European refugee crisis.

\section{Characterization of immigrants}

The terms immigrant, refugee, and asylum seeker in a broader context are used to describe people who fled their homes and moved to another country. It is crucial to differentiate between refugees, migrants, and asylum seekers, as the designation of these groups determines the eligibility to 
different levels of support and protection under international law (Anadia, 2020).

Immigrants are defined as people who are foreign-born and moved to a particular host country at a certain point for reasons including education, job seeking, or reuniting with their family members. Not all immigrants flee their countries due to threats and cannot be considered asylum seekers or refugees, as some people move to other countries for personal reasons (Amnesty International, 2020). Although the refugees and asylum seekers both come under the umbrella of immigrants, one of the common categories of immigrants to Europe during the past decade were economic migrants, whose primary incentive was economic gain and to seek better life opportunities.

Refugees, on the other hand, are the people who leave their home countries unwillingly because of war, violence, or justifiable fear of being mistreated or persecuted for their association to a certain religion, nationality, ethnicity, sexuality, and/or affiliation to a certain political or social group (UNHCR, 2020). A large number of refugees who arrived in Europe during 2015-2016 mainly came from Syria, Afghanistan, South Sudan, and Iraq.

Asylum seekers are the people who are at risk of human rights violations, forced to flee due to threat of war or persecution and seeking international protection under the 1951 Refugee Convention on the Status of Refugees (UNHCR, 2011). Although most refugees are at some point asylum seekers, whose asylum claim hasn't been legally approved, not every asylum seeker will necessarily be accepted as a refugee. However, in case of mass influx situations around the world, the UN considers the nationals of some countries (for example, Syria, Eritrea, Venezuela) as refugees even before their asylum claim is approved (Refworld, 2015), due to the risk of persecution and human rights threats.

Although, violence, mistreatments, and poverty in Afghanistan, Iraq, Eritrea, Sudan, and Kosovo, had been leading people to look for better lives in Europe, however, the conflict in Syria continues to be by far the biggest driver of migration to Europe. Even though a good number of Syrian and African refugees were educated and young, the Europeans remain concerned as the vast majority of asylum seekers who arrived in Europe after 2015 were uneducated and from poor backgrounds. Although, there were several cases of Christian and Jew asylum seekers forced out of Iraq and Syria, most of the refugees who came to Germany were Muslims (BAMF, 2015), which instigated fears that these refugees might not be able to integrate into the European society and cause further cultural, social and economic problems for Europe in the future (Rommel, 2017).

The shift in Germany's policy to facilitate the asylum claims of refugees who entered the country during 2015 and 2016 led to a significant increase in the overall refugee population that increased rapidly from 316,100 
in 2015 to 669,500 in 2016. By the end of the year, Germany became the country with the largest asylum-seeker population in the world (UNHCR, 2016). Therefore, the next part of the paper will address the shift in Germany's approach towards refugees and discuss key policies that facilitated the flow of refugees into the country.

\section{Germany's policies towards refugees}

Soon after the crisis emerged, German Chancellor Angela Merkel's confident statement "We have managed so much, we will manage it (Wir schaffen das)" (Scally, 2020) encouraged the local population to engage in voluntary activities to facilitate the integration process and support the refugees. Within a year, Germany gained the reputation of the most hospitable country towards refugees and accepted more than one million asylum seekers, who arrived in Europe from the war-torn Middle East and North African region.

At the beginning of the crisis, hundreds of thousands of refugees started queuing up in the Balkans to Austrian-German borders. The arrival of refugees at EU borders caused public disorder and the poor conditions of asylum seekers further raised humanitarian concerns all over the world. At that point, German Chancellor Merkel termed the issue of asylum as one of the biggest challenges to Europe's stability (Bundesregierung, 2015) and for Germany's administration, refusing entry to refugees into Germany was considered as devastating for the whole of Europe not only from social security but also from the political and humanitarian perspective. Merkel's statements on refugees indicate the seriousness of the crisis and Germany's concerns towards the issue that she believed would affect the whole of Europe in the years to come.

Consequently, German Chancellor Angela Merkel emerged as a frontrunner in dealing with the refugee crisis and urged the EU nations to have a common response on the issue (Scotti, 2015). Merkel also allocated 6 billion euros to help the incoming refugees and suggested that the country was ready to take about a million refugees to take the burden off other European countries.

As the influx of refugees reached its peak in 2016, German politicians realized that the new wave of immigrants could not be assimilated into the society due to the fact that there was a clear language barrier, newcomers were mostly uneducated and lacked previous work experiences and job-related skills. Therefore, with the support of the Federal Ministry of Labor and Social Affairs, Germany passed an ordinance on job-related German language support which was directly funded by the federal government and aimed at linking language acquisition with professional training, employment and labor market integration (BMAS, 2016). In addition to vocational training and 
integration courses, the government also provided transportation and childcare cost reimbursements to the participants and better financial incentives for the teachers and working staff (BMAS, 2016).

Although the federal government was mainly responsible for setting the legal framework for accessing labor market integration and vocational courses for the immigrants (OECD, 2017), the German federal states and municipalities had been instrumental in the implementation of policies, developing integration structures as well as providing job opportunities and labor market integration services. Moreover, the Federal Office for Migration and Refugees and the Federal Employment Agency played their respective roles in developing German language courses for refugees and supporting asylum seekers with professional training and job-related skills (OECD, 2017).

For decades, Germany has enacted several policies to turn guest workers into settlers with permanent-resident rights and the number of refugees through constitutionally protected family immigration policy has increased significantly (Joppke, 1998). Similarly, after the 2015 refugee crisis, the Merkel administration focused on family reunion projects that provided Syrian refugees with the opportunity to reunite with their family members in Turkey and Lebanon and allowed them to resettle in Germany under humanitarian admissions criteria. The government-funded project was mainly aimed at the refugees in need of international protection who faced legal obstacles and practicality issues (UNHCR, 2016).

Furthermore, Germany adopted policies to avoid disproportion in refugees' settlements and ensure that the newcomers were settled all over the country. To prevent refugees from moving to places already populated by migrants, the government further restricted the refugees to reside in their assigned locations during the first three years of their stay (Karolewski \& Benedikter, 2018). The local authorities were tasked to sort the logistics, while volunteers and social workers played a crucial role in the integration, training, and settlement process of the refugees who were housed in different parts of Germany. The social workers and civil society members of Germany vigorously supported the government's integration policies and the members of counseling services accompanied the refugees in every step from their status recognition, administrative procedures, to housing and integration (Wiese, 2019). The dedicated local citizens provided refugees and asylum seekers with help based on each individual's needs, ranging from educational matters, personal coaching, health care services, job opportunities to recreational activities (OECD, 2018).

By the end of 2016, the refugee and asylum-seeker population in Germany reached 1.3 million (UNHCR, 2016) and the government faced the additional challenge of integrating those newcomers. In this regard, Germany 
introduced a number of projects to support the refugees, including public welfare-oriented employment initiatives with low requirements, private sponsorship projects, labor schemes, and education programs.

The federal government also launched campaigns to integrate refugees through education. Initially, the four-year project received funding of 100 million euros and was aimed at preparing refugees for academic and school courses. The government also allocated special financial aid and student loans for asylum seekers and tolerated refugees. Similarly, German schools and universities also exempted admission test fees for asylum seekers and offered restriction-free campus access to the refugees (Trines, 2019).

However, Merkel's policies witnessed some backlashes and governing authorities were blamed for social disorder and risking internal security, as some associated refugees with radicalism and considered them a burden on society (Peters, 2016). The government policies on immigrants also polarized Germany and led the far-right AfD party to gain considerable presence in parliament, which led to the rise in anti-refugee and anti-Islam sentiments in the society (Sola, 2018). Moreover, authorities were overwhelmed due to the huge influx of refugees and increasing internal pressures induced the German parliament to pass legislation to discourage new immigrants to the country (Bundestag, 2019). However, despite the limitations to previous lenient laws and increased restrictions towards immigrants, the acceptance rate of humanitarian migrants remains high and Germany continues to accept the highest number of asylum applications in the EU (Eurostat, 2021).

Therefore, the next part of the paper will analyze the possible factors for Germany to adopt lenient policies towards the immigrants that entered the country during the 2015-2016 refugee crisis and discuss the rationale of Germany's positive attitude and decision-making process.

\section{Analysis of Germany's attitude towards immigrants}

Several researchers have attempted to solve this puzzle and unfold the reasons behind Germany's positive attitude towards immigrants. Existing literature on theories of immigration policy mainly addresses the issue from the perspectives of socio-economic, foreign policy, and national identity, as well as discusses the roles of different institutions and human rights bodies on policy making (Hollifield 1992, 2000; Freeman 1995; Meyers 2000; Boswell 2007; Bonjour 2011).

\section{Economic Incentives}

Most researchers argue that Germany's increasing aging population pose difficulties to maintain the economic growth of the country, and manual labor jobs don't appeal to many young native Germans (Reuters, 2015). Moreover, the argument that immigrants usually take over the lowest positions 
in the society, while the locals can enjoy the better ones, can also affect the attitude towards the immigrants (Zogata-Kusz, 2012).

Freeman (1995) argues that parties that can benefit from the cheap labor force are more likely to accept refugees. Therefore, they utilize their influence and initiate collective actions for lenient policies towards immigrants. Scholars who support this argument claim that economic incentive was one of the main factors prompting Germany's decision to take refugees, who could serve as a solution for Germany's job market.

Brochmann (1999) also establishes a link between the interests of economic actors and the positive attitude towards immigrants, as labor unions aim to maximize their profit and strengthen their position by supporting refugees. Similarly, companies that may benefit from immigrants do not only support the government's policies to allow new immigrants but also directly participate in training and promotion of job-related projects to speed up the labor market integration.

However, scholars who refute such claims, argue that to consider that refugees could provide a solution to the lack of skilled workers in the short term is detrimental. According to labor economist Ulf Rinne, the claim that refugees might alleviate the demographic problems in Germany in the long term was questionable and possible only if they are well integrated into the labor market (Reuters, 2015).

Similarly, according to Fratzscher and Junker (2015) annual expenditures on facilitating the integration process amounted to enormous 12,000 euros per refugee, including direct payments, recruitment of additional public administration workers, language teachers, as well as construction costs for building homes and facilities for new asylum seekers. Fratzscher and Junker (2015) argue that although the efforts would lead to long-term benefits for the German economy, the initial cost that the German government had to bear was a huge burden. The German government spent around 20 billion euros on migration-related issues in 2016 alone (DW, 2017) and is expected to spend about 78 billion euros on integrative measures through 2022 (Reuters, 2018).

Moreover, Trines (2017) argues that language barriers, getting acquainted with the German culture, law and society, created further integration problems for immigrants, as most of the refugees did not have the academic skills and work experience that is required in Germany, and consequently, the chances for them to be employed are far less compared to local Germans.

In conclusion, the analysis of the literature suggests that workforce integration of the refugees is a long-term process and it is unlikely that Germany accepted more than a million refugees merely for financial profit. 
Therefore, the next part of the paper will explore some other factors, such as foreign policy, ideological, and humanitarian concerns.

\section{Foreign policy considerations}

For decades the issue of immigration was considered low politics in international relations, however, since the late 1990s more scholars began to analyze the implication of immigrants on security, foreign policy, and other high politics issues (Hollifield, 2000).

This leads to another prevalent argument concerning the role of foreign policy in shaping immigration rules. The realist approach suggests that states utilize their resources to secure interests and foreign policy objectives, which includes strengthening the international image and emerging as an important political actor. Therefore, some scholars argue that Germany's political leadership adopted an open-door policy towards refugees in a bid to improve the international image and demonstrate their ideological positions as a liberal democratic country.

Weiner (1985) argues that the immigration issue has a direct influence on foreign policy as immigrants can affect the politics of both the receiving and the sending countries. However, Weiner believes that liberal democracies are often concerned about their international image and accept refugees to remain respected and trustworthy members of society. While democratic countries may restrict the economic immigrants, however, due to human rights concerns and maintain their image, they cannot restrict family reunification and have to allow refugees (Hollifield 1992, 584).

Escribà-Folcha and Wright (2015) argue that countries seek to ensure their political and economic survival by cooperating with other global and regional powers. This notion is further elaborated by Hollifield (1992) that countries are careful in dealing with matters related to civil and immigrants' rights and tend to formulate lenient policies towards refugees due to foreign policy considerations. In the case of Germany, Merkel administration was faced with the dilemma of parallel societies, however, the German government chose to protect immigrant's rights by enacting a number of policies to facilitate incoming refugees.

German political scientist Hans Vorlaender argues that Merkel has done Germany a great service from a moral point of view, but he believed that by doing so Merkel did not consider the EU's opinion and implemented her policies without any feasible plan, national consent or consultation (Kirschbaum, 2016). This perspective suggests that although Merkel's decision to open borders and allow refugees did take some pressure off neighboring countries, she did not exclusively take foreign policy considerations into account. This notion suggests that although foreign policy considerations have been a major factor in formalizing refugee policies, the 
German administration did not exclusively consider foreign policy while dealing with the refugee crisis, therefore it is worth exploring other factors to understand Germany's stance towards refugees.

\section{Ideological concerns}

Another group of scholars argues that different cultures, religions and ideologies between the receiving and sending countries can play an important role in shaping immigration policy and according to Meilaender, (2001) refugees who might challenge essential features of the national identity of the receiving country are hardly ever accepted by societies. Similarly, Weiner (1995) points out that fear of foreigners and perception of negative effects of migration on culture and economy may also affect the society's decision to accept refugees. Tsoukala (2005) also argues that countries with strong identity principles may consider immigrants as a threat to demographic balance, and consider refugees a security threat.

Triadafilopoulos (2012) believes that increasing demands of the labor market and global norms against racism encouraged the German government to accept immigrants, promote a multicultural society and end racist immigration. However, due to lack of experience as a receiving country of multicultural immigrants, the German population is faced with the threat of losing national identity (Triadafilopoulos, 2012) and struggling to accept the huge influx of refugees.

In this regard, Wiese (2019) argues that states are often vacillating between the rights of citizens and the rights of immigrants, as governments seek to legitimize their authority by keeping a balance between the needs of domestic society and immigrants. When a state receives refugees, it faces a challenge of parallel societies (Wiese, 2019) where on one hand it has an obligation to attend the security and ideological concerns of its citizens and on the other hand address legal concerns of immigrants, therefore, states seek to achieve the social cohesion on an urgent basis to avoid the challenges of parallel societies and societal conflicts.

Since Germany opened its borders for refugees, the country became somewhat divided and witnessed an increase in societal conflicts. The emergence of far-right groups and the rise of anti-refugee sentiments not only posed challenges for Merkel's administration but also affected the integration process. Nevertheless, after half a decade most Germans are satisfied with the overall integration process and Germany somewhat managed to overcome the challenge of parallel societies. Wiese (2019) points out that since Germany's reunification and the formation of the EU, the German population became less concerned about the border security issues and more open to the ideas of globalization and open borders. 
However, Meyer (2015) argues that one of the reasons for Germany to have positive results in social and labor market integration is because many Germans are not attracted to the idea of patriotism and remain uncomfortable to define what being German means. Meyer (2015) claims that due to historical experiences, for some Germans, patriotism is considered as the root of evil. Instead, they feel proud of Germany for accepting immigrants and promoting diversity under the basic law. Meyer (2015) argues that most Germans consider themselves Europeans or regional citizens and 'Germany' remains abstract due to cultural diversity.

In accordance with Meyer's arguments, Kermani (2014) asserts that "the basic law is the manifestation of values which is in essence not German but... it applies to all who live here [in Germany]". Scholz (2014) also agrees with Kermani and stresses that the basic law of Germany serves as a guideline for immigration and harmony between different cultures. This notion suggests that ideological concerns often lead nations to take harsh stances towards refugees, however, according to the above discussed arguments, the German society was less patriotic and more open to accept refugees. Similarly, the German administration was ostensibly more concerned about the human rights concerns, therefore the next part will explore the factor of human rights concern.

\section{Human rights concerns}

The basic law and human rights include the rights of immigrants and some scholars argue that the rise of international human rights bodies, accountability mechanisms and globalization have limited the power of states to restrain the rights of the immigrants (Sassen 1996; Joppke 1998). Moreover, in Germany, the role of immigration and asylum lawyers, social workers and the business sector is crucial since they not only influence the policymakers through lobbying but also play an important role in the settlement process for refugees (Wiese, 2019).

The theorists of globalization argue that in international relations the role of non-state actors such as humanitarian organizations, civil society and transnational communities can directly influence the decision-making process of the state actors. The positive role played by the German civil society in support of refugees was a prominent example of such an argument. As refugees arrived in Germany in huge numbers, volunteer enterprises were established all over the country (Heckmann, 2016).

Sassen (1999) argues that although states play a major role in the development and implementation of immigration policy, the autonomy of states has decreased. Meyers (2000) also claims that although states execute policies independently, ethnic groups and non-governmental organizations can sometimes modify their decisions. Scholars who study the issue from a 
globalist approach argue that transnationalism has declined the sovereignty of a nation-state (Overbeek 2000), thus the policies on immigration are directly influenced by non-state actors.

Triadafilopoulos (2012) argues that historical events such as decolonization and the rise of global human rights culture influenced liberal democracies' perception of immigration and citizenship. Similarly, he claims that Germany's attitude towards immigrants and asylum seekers is directly affected by the international norms and refugee protection laws.

Germany's population is composed of diverse culture, religion and ethnicity and have lived in the country for generations. In the 60s and 70s, millions of Turkish, Spanish and Greek immigrants who migrated to Germany were considered peaceful settlers and today their children and grandchildren constitute a key part of German society (BAMF, 2005). Although, the refugees that arrived in Germany during the 2015-2016 crisis mainly came to Europe on humanitarian grounds and lacked work skills, the previous successful cases of integration and coherencies between the policies on paper and policy implementation helped shape the positive attitude among the locals and the constructive roles of local government agencies and civil society further eased the integration process.

Germany's past experiences of successful integration helped build confidence among the German policymakers and helped shape the policy towards the refugees during the 2015 crisis. Hindy (2018) points out that the German administration learned from the past mistakes and concentrated on social and labor market integration by introducing language courses and entrepreneurship policies for immigrants and effectively coordinating between federal, state, and local authorities.

The analysis of human rights concerns argument advocates that the German government was concerned with a negative spillover effect if their policies were to be negative towards refugees, and, human rights concerns remain a major factor that influences countries' immigration policies. Similarly, the German administration's efforts to highlight the humane aspect of the refugee crisis, the increasing role of civil societies and humanitarian organizations in Germany reflects the country's adherence to human rights norms and protection of refugees.

The analysis of literature also suggests that the German administration attached great importance to the humanitarian aspect and was somewhat confident in its capability to integrate incoming refugees, therefore swiftly utilized resources and civil society members to accommodate and integrate the immigrants that arrived Germany during the height of refugee crisis. 


\section{Conclusion}

The theoretical analysis suggests that the aspect of humanitarian concern is considered to be one of the primary reasons for Germany's lenient policies towards immigrants, however, the aspect based on the individual level remains less explored. Although some scholars have acknowledged the effects of moral values among the individuals on immigration policies, only a handful of scholars have studied the role of humanitarian values influencing the leaders who shape refugee policies. It is worth noting that when Merkel was criticized for opening borders for refugees, she resolutely stood by her decision and stated that "there is one red line that we should not cross... it is a commitment to human rights, the respect of the dignity of the human being, and there should be no compromises" (McCarthy, 2017). Similarly, Stelzenmüller (2020) points out that Merkel grew up in Eastern Germany which might have influenced her viewpoints and decisions that are based on humanitarian and moral values. Similarly, some Germans feel morally obliged to help refugees as they have better living standards and high social values, therefore, they consider it their responsibility to help people from Syria and other war-torn countries.

For the most part, Merkel's policies on refugees were applauded for moral and humanitarian reasons. Although on a national scale, Merkel's decisions fueled the rise of the anti-immigrant factions and divided Germany, internationally, she became a global icon due to her compassion towards the refugees. Five years after Germany's refugee influx, despite numerous criticisms, Merkel claims that she does not regret her verdict in 2015 and would make the same decision again (Page, 2020). Nonetheless, Germany still faces the refugee and integration crisis, as the German Chancellor indicated that the issue will remain a major concern in the years to come (Page, 2020).

After half a decade, Germany's policies towards immigrants paid off as the country successfully managed to integrate a remarkable number of refugees. The overall integration experience of immigrants in Germany is a success story and this positive attitude towards refugees can be traced back to the past experiences of integration in Germany. However, it was observed during the study that most scholarly researchers did not take into account the factor of Germany's past experiences of social integration, which provided German policymakers the confidence in well-established institutions and capacity to integrate the incoming refugees. Although the 2015 crisis exposed some of the limitations in Germany's integration system, the country effectively improved its integration framework. With a favorable labor market environment and positive efforts of the administration and civil society, Germany swiftly implemented policies to facilitate the integration of immigrants. 
Moreover, the role of historical reasons can also help understand why Germany did not close the doors to war refugees, and the relations between national guilt/past experiences and high moral values among the German population could also be the focus of future studies. As Wiese (2019) argues that sufferings that were inherited by German people after the second world war including large displacement and human rights violations have had a socio-psychological effect on the German population and lessons from the past played an important role in German leadership's decision-making, particularly regarding policies on immigrants and displaced citizens.

\section{References:}

1. Amnesty International (2020). Refugees, Asylum-seekers and Migrants. AI. Retrieved from https://www.amnesty.org/en/what-wedo/refugees-asylum-seekers-and-migrants/

2. Anadia, L. (2020). Everything that's wrong with the Economy these days. ALFA. Retrieved from

https://www.limoeirodeanadia.al.gov.br/portal/2019/09/09/everything -thats-wrong-with-the-economy-these-days/

3. BAMF (2005). The Impact of Immigration on Germany's Society. Federal Office for Migration and Refugees. Retrieved from https://ec.europa.eu/home-affairs/sites/default/files/what-wedo/networks/european_migration_network/reports/docs/emnstudies/illegally-resident/de-finalstudy-eng_en.pdf

4. BAMF (2015). Migrationsbericht 2015 des Bundesamtes für Migration und Flüchtlinge im Auftrag der Bundesregierung. Retrieved from

https://www.bamf.de/SharedDocs/Anlagen/DE/Publikationen/Migrati onsberichte/migrationsbericht-2015.pdf?_blob=publicationFile

5. BMAS (2016). Verordnung uber berufsbezogene Sprachforderung passiert Kabinett. Bundesministerium fur Arbeit und Soziale. Retrieved from https://www.bmas.de/DE/Presse/Pressemitteilungen/2016/verordnun g-ueber-berufsbezogene-sprachfoerderung-passiert-kabinett.html

6. Bonjour, S. (2011). The Power and Morals of Policy Makers: Reassessing the Control Gap Debate. International Migration Review, 45(1), 89-122.

7. Boswell, C. (2007). Theorizing Migration Policy: Is There a Third Way?. International Migration Review, 41(1), 75-100.

8. Brochmann, G. (1999). Controlling Immigration in Europe. Brochmann, G. and Hammar, T. (eds.), Mechanism of Immigration Control: A Comparative Analysis of European Regulation Policies, 297-334. Oxford, UK: Berg Publishers. 
9. Brücker, H., Kosyakova, Y., Schuß, E. (2020). Integration in Arbeitsmarkt und Bildungssystem macht weitere Fortschritte. Institute for Employment Research, p. 15. Retrieved from https://doku.iab.de/kurzber/2020/kb0420.pdf

10. Bundesregierung (2015). Merkel ZDF interview. Refugee policy: finding common answers. Retrieved from https://www.bundesregierung.de/breg-en/news/refugee-policyfinding-common-answers-443560

11. Bundestag (2019). Bundestag stimmt fur Gesetzentwurfe zum Asylund Aufenthaltsrecht. Deutscher Bundestag. Retrieved from https://www.bundestag.de/dokumente/textarchiv/2019/kw23-deausreisepflicht-645888

12. DW (2017). Germany spent 20 billion euros on refugees in 2016. Deutsche Welle. Retrieved from https://www.dw.com/en/germanyspent-20-billion-euros-on-refugees-in-2016/a-38963299

13. Escribà-Folcha, A., Wright, J. (2015). Foreign Pressure and the Politics of Autocratic Survival, p. 5. Oxford: Oxford University Press.

14. Eurostat (2021). Asylum statistics. Eurostat Statistics Explained. Retrieved from

https://ec.europa.eu/eurostat/statisticsexplained/index.php?title=Asylum_statistics\#Main_countries_of_des tination:_Germany.2C_Spain_and_France

15. Fratzscher, M., Junker, S. (2015). Integrating Refugees: A Long-Term, Worthwhile Investment. DIW Economic Bulletin. German Institute for Economic Research, 5(45/46), p. 612-616.

16. Freeman, G. P. (1995). Modes of Immigration Politics in Liberal Democratic States. International Migration Review, 29(4), 881-902.

17. Heckmann, F. (2016). Understanding the Creation of Public Consensus: Migration and Integration in Germany 2005 to 2015. Migration Policy Institute. Retrieved from https://www.migrationpolicy.org/sites/default/files/publications/TCM _Trust-Germany-FINAL.pdf/

18. Hindy, L. (2018). Germany's Syrian Refugee Integration Experiment. The Century Foundation Report. Retrieved from https://productiontcf.imgix.net/app/uploads/2018/09/03160422/germanys-syrianrefugee-integration-experiment.pdf

19. Hollifield, J. F. (1992). Migration and International Relations: Cooperation and Control in the European Community. International Migration Review, 23(2), 568-595.

20. Hollifield, J. F. (2000). The Politics of International Migration: How Can We Bring the State Back In?. Brettel C. and Hollifield J. F. (eds.) Migration Theory: Talking across Disciplines, 137-185. Routledge. 
21. Joppke, C. (1998). Why Liberal States Accept Unwanted Immigration. World Politics, 50(2), 266-293.

22. Karolewski, I., Benedikter, R. (2018). Europe's Refugee and Migrant Crisis: Political Responses to Asymmetrical Pressures. Politique Européenne, 2(2), 98-132. Retrieved from https://doi.org/10.3917/poeu.060.0098

23. Kermani, N. (2014). Ceremony at the German Bundestag Celebrating the 65th Anniversary of the Entry into Force of the Basic Law for the Federal Republic of Germany. Navidkermani.de, p. 62. Retrieved from https://www.btg-bestellservice.de/pdf/20099850.pdf

24. Kirschbaum, E. (2016). Germany opened its doors to refugees a year ago, but some residents have had enough. LA Times. Retrieved from https://www.latimes.com/world/europe/la-fg-germany-refugeesfallout-snap-story.html

25. Massey, D. S. (1999). International Migration at the Dawn of the 21st Century: The Role of the State. Population and Development Review, 25(2), 303-322.

26. McCarthy, J. (2017). 11 Quotes That Show Angela Merkel Is a True Global Citizen. Global Citizen. Retrieved from

https://www.globalcitizen.org/en/content/11-quotes-that-showangela-merkel-is-a-true-global/

27. Meilaender, P. C. (2001). Toward a Theory of Immigration. Houndmills, UK: Palgrave Macmillan, p. 82.

28. Meyers, E. (2000). Theories of International Immigration Policy - A Comparative Analysis. International Migration Review, 34(4), 12451282.

29. Meyer, J. (2015). Why is Germany Taking in So Many Refugees?. Slate. Retrieved from https://slate.com/human-interest/2015/09/syriamigration-crisis-why-is-germany-taking-in-so-many-refugees.html/

30. OECD (2017). Finding their Way: Labour Market Integration of Refugees in Germany. OECD Publishing, Paris, 26-27. Retrieved from https://www.oecd.org/els/mig/Finding-their-Way-Germany.pdf

31. OECD (2018). Working Together for Local Integration of Migrants and Refugees. OECD Publishing, Paris, p. 119. Retrieved from https://doi.org/10.1787/9789264085350-en

32. Overbeek, H. (2000). Globalization, Sovereignty, and Transnational Regulation: Reshaping the Governance of International Migration. Bimal Gosh (ed.) Managing Migration: Time for a New International Regime, 48-74. Oxford University Press.

33. Page, I. L. (2020). Merkel 'would do the same again' five years after Germany's refugee influx. The Local. Retrieved from 
https://www.thelocal.de/20200828/merkel-would-do-the-same-againfive-years-after-germanys-refugee-influx

34. Peters, M. E. (2016). Goods versus people: immigration and trade policy in a globalized world. Handbook on Migration and Social Policy, 87-107.

35. Refworld (2015). Guidelines on International Protection No. 11: Prima Facie Recognition of Refugee Status. UNHCR. HCR/GIP/15/11. Retrieved from https://www.refworld.org/docid/555c335a4.html

36. Reuters (2015). There's a very practical reason why Germany is taking in so many refugees. Business Insider. Retrieved from

https://www.businessinsider.com/r-in-ageing-germany-refugees-seenas-tomorrows-skilled-workers-2015-9

37. Reuters (2018). Germany sees migration-related spending of 78 billion euros through 2022: report. Thomson Reuters. Retrieved from https://www.reuters.com/article/us-germany-budget-

migrants/germany-sees-migration-related-spending-of-78-billioneuros-through-2022-report-idUSKCN1IK0EG

38. Rommel, I. (2017). "We are the People" Refugee-"Crisis", and the Drag-Effects of Social Habitus in German Society. Historical Social Research, Vol. 42, No. 4 (162), 133-154.

39. Sassen, S. (1996). Beyond Sovereignty: Immigration Policy Making Today. Social Justice, 23(3), 9-20.

40. Sassen, S. (1999). Beyond Sovereignty: De-Facto Transnationalism in Immigration Policy. European Journal of Migration and Law, 1(2), 177-198.

41. Scally, D. (2020). Germany feels quiet pride five years on from refugee crisis. Irish Times. Retrieved from https://www.irishtimes.com/news/world/europe/germany-feels-quietpride-five-years-on-from-refugee-crisis-1.4335140/

42. Scholz, K. (2014). Time for More Pride in German Constitution. DW. Retrieved from https://www.dw.com/en/opinion-time-for-more-pridein-german-constitution/a-17659073/

43. Scotti, V. (2015). EU and Migration - What are the real questions?. Philosophical Club. http://philosophyclub.bg/eu-and-migration-whatare-the-real-questions/

44. Sola, A. (2018). The 2015 Refugee Crisis in Germany: Concerns about Immigration and Populism. German Socio-Economic Panel (SOEP) Papers on Multidisciplinary Panel Data Research at DIW Berlin, p. 3. Retrieved from https://www.diw.de/documents/publikationen/73/diw_01.c.583437.de /diw_sp0966.pdf 
45. Stelzenmüller, C. (2020). Merkel's legacy and the future of German politics. Interview with Benjamin Haddad. Retrieved from https://twitter.com/benjaminhaddad/status/1301551671902760961

46. Triadafilopoulos, T. (2012). Becoming Multicultural Immigration and the Politics of Membership in Canada and Germany, pp. 13-18, p. 158. Vancouver: UBC Press.

47. Trines, S. (2017). Lessons from Germany's Refugee Crisis: Integration, Costs, and Benefits. WENR. Retrieved from https://wenr.wes.org/2017/05/lessons-germanys-refugee-crisisintegration-costs-benefits/

48. Trines, S. (2019). The State of Refugee Integration in Germany in 2019. WENR. Retrieved from https://wenr.wes.org/2019/08/the-stateof-refugee-integration-in-germany-in-2019

49. Tsoukala, A. (2005). Looking at Migrants as Enemies, in Didier Bigo and Elspeth Guild (eds.) Controlling Frontiers: Free Movement into and within Europe, 161-192. Aldershot, UK: Ashgate.

50. Weiner, M. (1985). On International Migration and International Relations. Population and Development Review, 11(3), 441-455.

51. Weiner, M. (1995). The Global Crisis: Challenge to State and to Human Rights, 135-138. New York, NY: HarperCollins.

52. Wiese, L. (2019). Refugees welcome? How Germany, Canada, and Australia respond to contemporary migration. 55-56, 67, 197, Doctoral thesis submitted at University of Konstanz. Retrieved from https://nbnresolving.de/urn:nbn:de:bsz:352-2-1xsrf51s24wry8/

53. UNHCR (2011). The 1951 Convention relating to the Status of Refugees and its 1967 Protocol. UN Refugee Agency, p. 1. Retrieved from https://www.unhcr.org/about-us/background/4ec262df9/1951convention-relating-status-refugees-its-1967-protocol.html

54. UNHCR (2015). Worldwide displacement hits all-time high as war and persecution increase. UN Refugee Agency. Retrieved from https://www.unhcr.org/news/latest/2015/6/558193896/worldwidedisplacement-hits-all-time-high-war-persecution-increase.html

55. UNHCR (2016). Global Trends: Forced Displacement in 2016. Retrieved from

https://www.unhcr.org/statistics/unhcrstats/5943e8a34/global-trendsforced-displacement-2016.html

56. UNHCR (2020). Convention Relating to the Status of Refugees. UNHCR. p. 3. Retrieved from https://www.unhcr.org/3b66c2aa10.pdf 